University of Nebraska - Lincoln

DigitalCommons@University of Nebraska - Lincoln

USDA Wildlife Services - Staff Publications

U.S. Department of Agriculture: Animal and Plant Health Inspection Service

$12-1-2021$

\title{
Economic Estimates of Wild Hog (Sus scrofa) Damage and Control Among Young Forest Plantations in Alabama
}

\author{
Micah Fern \\ Union University, mfern@uu.edu \\ Rebecca Barlow \\ Auburn University \\ Chris Slootmaker \\ Mountain Data Group \\ John Kush \\ Auburn University \\ Stephanie Shwiff \\ USDA APHIS National Wildlife Research Center \\ Follow this and additional works at: https://digitalcommons.unl.edu/icwdm_usdanwrc

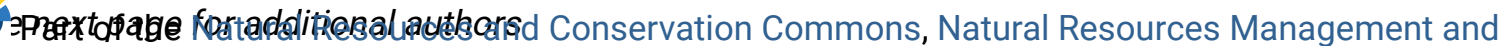 \\ Policy Commons, Other Environmental Sciences Commons, Other Veterinary Medicine Commons, \\ Population Biology Commons, Terrestrial and Aquatic Ecology Commons, Veterinary Infectious Diseases \\ Commons, Veterinary Microbiology and Immunobiology Commons, Veterinary Preventive Medicine, \\ Epidemiology, and Public Health Commons, and the Zoology Commons
}

Fern, Micah; Barlow, Rebecca; Slootmaker, Chris; Kush, John; Shwiff, Stephanie; Teeter, Larry; and Armstrong, Jim, "Economic Estimates of Wild Hog (Sus scrofa) Damage and Control Among Young Forest Plantations in Alabama" (2021). USDA Wildlife Services - Staff Publications. 2469.

https://digitalcommons.unl.edu/icwdm_usdanwrc/2469

This Article is brought to you for free and open access by the U.S. Department of Agriculture: Animal and Plant Health Inspection Service at DigitalCommons@University of Nebraska - Lincoln. It has been accepted for inclusion in USDA Wildlife Services - Staff Publications by an authorized administrator of DigitalCommons@University of Nebraska - Lincoln. 


\section{Authors}

Micah Fern, Rebecca Barlow, Chris Slootmaker, John Kush, Stephanie Shwiff, Larry Teeter, and Jim Armstrong 


\title{
Economic Estimates of Wild Hog (Sus scrofa) Damage and Control Among Young Forest Plantations in Alabama
}

\author{
Micah Fern ${ }^{1}[1] \cdot$ Rebecca Barlow ${ }^{2} \cdot$ Chris Slootmaker $^{3} \cdot$ John Kush $^{2}$. \\ Stephanie Shwiff ${ }^{4} \cdot$ Larry Teeter $^{2} \cdot$ Jim Armstrong ${ }^{2}$
}

Accepted: 27 March 2021 / Published online: 10 April 2021

(c) Steve Harrison, John Herbohn 2021

\begin{abstract}
Operating as ecological engineers, the increased distribution and abundance of wild hogs (Sus scrofa) has caused considerable socio-economic impacts. The international scope of economic research providing wild hog damage estimates are often confined to agricultural crops, while damage estimates among forest plantations are lacking. In Alabama, private landowners hold the majority of timberland acreage and are less equipped to absorb financial losses from wild hog damage than their industrial counterparts. A survey was conducted to estimate the economic impact of wild hogs, namely costs of damage and control, to privately owned forestlands. The survey was distributed in the summer of 2016 to a sample of 1160 private landowners across the State. A 35\% response rate was achieved from the sampled group. Survey results indicated in 2013 to 2015 longleaf pine (Pinus palustris) and loblolly pine (Pinus taeda) were the only species damaged by wild hogs. Wild hogs caused damage to 34 and $13 \%$ of forest acres in longleaf and loblolly plantations, respectively. At $\$ 50.40$ per acre, costs associated with replanting damaged longleaf acres were double those for loblolly. Survey results suggest the southern half of Alabama holds the largest wild hog populations and sustained the most damage to forest stands. Consequently, landowners in this region invested the most capital on control methods where the average cost per control technique ranged from \$12-2750. Additionally, landowners who did not have wild hogs on their property were willing to pay around \$14 per acre more for eradication than those with. We hope the findings from this survey will provide a better understanding of the economic impact of wild hogs in young forest plantations.
\end{abstract}

Keywords Damage survey · Pine seedlings · Sus scrofa $\cdot$ Wild hog · Alabama · Forest plantation

Micah Fern

mfern@uu.edu

Extended author information available on the last page of the article 


\section{Introduction}

Ninety-four percent of Alabama's timberland acreage is privately owned with around $50 \%$ of the total timberland being pine plantations (AFC 2020). With Alabama's land area comprised of $27 \%$ farm operations and $69 \%$ timberlands, the deleterious effects from wild hog presence in the State is a major cause for concern (AFC 2020; USDA 2016). With isolated populations of wild hogs in at least 64 of the 67 counties in the state (Conley et al. 2014), this species has emerged as "the most destructive nuisance animal ever brought to Alabama" (Jaworowski 2011). Wild pigs impact timber stands in a variety of ways from rooting and girdling trees, to their most costly damage, depredation of planted pine seedlings (Mayer 2009). Fern et al. (2020) found that of the five planted pine and hardwood species tested in a young forest plantation, wild hogs preferred longleaf pine (Pinus palustris).

Funding to manage wild hogs and protect valuable resources is finite and must be applied carefully in order to optimize its use. When economic restraints govern the management actions that can be taken towards controlling wild hogs, the metric for success is measured by the amount and value of resources protected (Engeman et al. 2003). Therefore, providing an estimation of the monetary value to the damage wild hogs inflict on a resource would permit economic analyses to help guide and evaluate management actions (Engeman et al. 2003).

The international scope of economic research providing wild hog damage estimates are often confined to agricultural crops (Anderson et al. 2016; Herrero et al. 2006; Schley et al. 2008; Schley and Roper 2003; Seward et al. 2004), while damage estimates among forest plantations are lacking. We are unaware of any scientific literature which provides monetary estimates of the wild hog damage observed in young forests, either privately or industrial. To gain a better understanding of the socio-economic impact of wild hogs on privately owned forestlands, this project was designed as a companion piece to supplement the work done by Anderson et al. (2016). The goal of this project was to fill in the knowledge gap concerning the economic impact of wild hogs to young forest plantations. A survey was conducted to solicit information from non-industrial private landowners to estimate the costs associated with wild hog damage and control in young forest plantations located in Alabama. Such information is beneficial in guiding forest management decisions as the threat from wild hogs becomes more widespread.

\section{Methods}

The questionnaire created for this project was based on a prior survey conducted during the summer of 2015 (Anderson et al. 2016). In the Anderson et al. (2016) study, farmers from 11 states in the southern US were surveyed to assess the economic impact of wild hogs on crops, livestock, farmland, and the corresponding 
costs associated with wild hog control. Portions from the survey used for estimating damages were restructured to include questions relating to forestry. The survey was designed to simultaneously capture information related to wild hog presence on private lands and in forest stands, damage to forested areas, forest types, control methods, and hunting.

Survey questionnaires were administered and coordinated by the Auburn University School of Forestry and Wildlife Sciences during the summer of 2016 (Fig. 1). Thirty of the 67 counties in Alabama were randomly selected to receive survey questionnaires. A stratified random sample of approximately 1200 private landowners was taken from county tax roll records, equivalent to 40 samples from each of the selected counties. The participant population included non-industrial private landowners owning 20 or more acres who were age 19 or older and owned land in Alabama. All landowners with less than 20 acres, age 18 or younger, or landowners associated with the timber industry were excluded. Since we were not able to determine forested acres, we used the 20 -acre minimum in an effort to improve the chance that the land would be forested.

The mailing of the questionnaire and the timing of implementation was in accordance with the recommendations made by Dillman's et al. (2014) Tailored Design Method. This included a pre-notice letter, survey questionnaire,

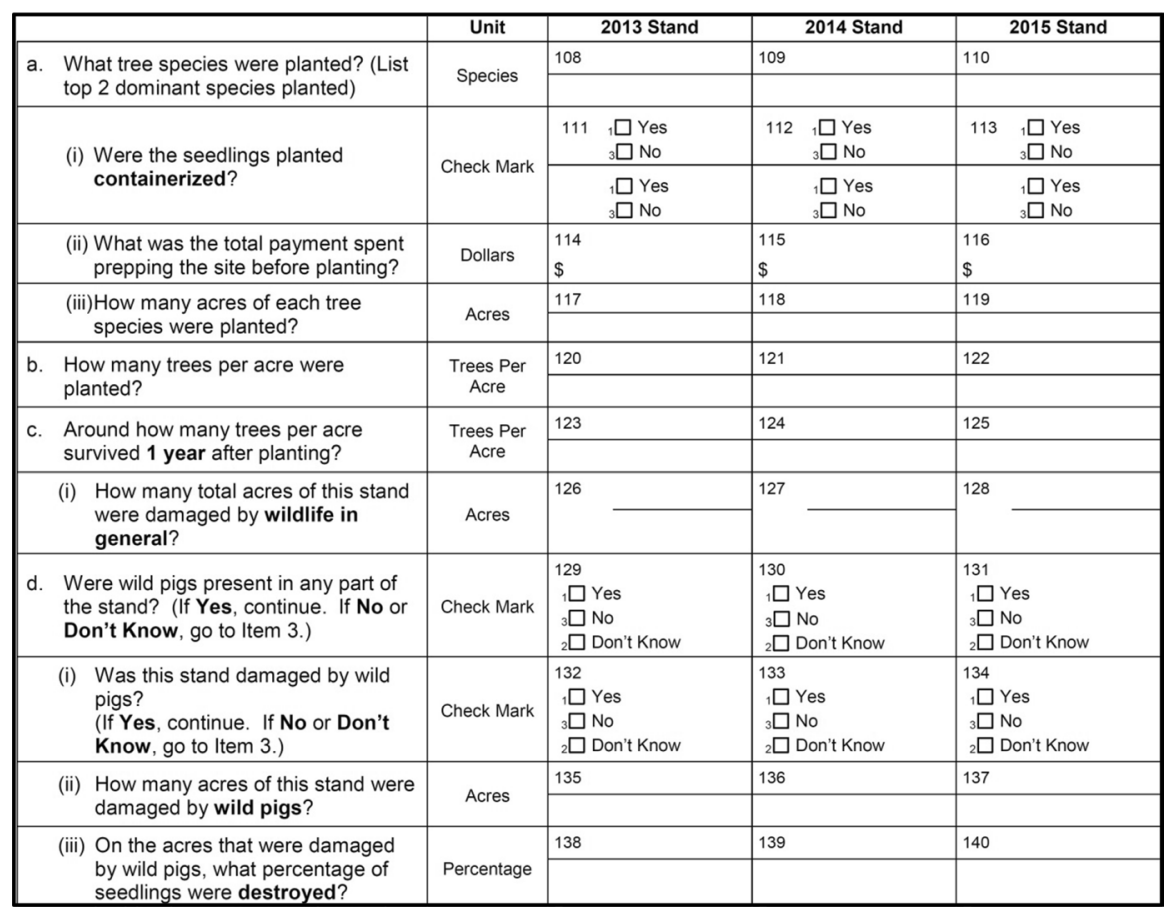

Fig. 1 Questions from survey instrument used to gather information about Alabama landowner's forest operation from 2013 to 2015 and any resulting wild hog damage to the stand 
follow-up letter, and second-round survey questionnaire. The survey followed research protocol approved by Auburn University's Institutional Review Board.

Information on damage to young forest plantations was inferred by the questions listed in Fig. 1. Landowners could choose to include their top two timber crops planted each year from 2013 to 2015. Even if the landowners did not experience wild hog damage, the survey questions were structured in such a way that useful information about their forest plantation could still be captured. Questions in this section also included asking landowners to provide the number of acres damaged by wild hogs for each tree species planted and an estimate of the percentage of seedlings destroyed on those acres.

Survey participants were asked to give information on the efforts used to control wild hogs on their property (Fig. 2). Specifically, participants were questioned about the control methods used, the dollar amount invested in each method, and their perception on how effective the method was at controlling wild hogs. Questions about fencing, both non-electric and electric, were formatted differently from the control methods because they were categorized as fixedcost. Lastly, landowners were asked to report how many wild hogs were killed on their land in 2015 and if they sought help from any county, state, or federal agencies in response to wild hog damage on their property.

In order to gauge landowner preferences for wild hog density and willingness to pay for eradication, participants were asked to select a category which best reflected their situation and opinion of wild hogs on their property or area (Fig. 3). In responding to this question, landowners would indicate the current status of wild hogs on their property and whether they would prefer more, fewer, or no change in wild hog density. The questionnaire was designed to group participants into those who preferred wild hogs and those who did not. Respondents would then indicate a dollar amount from $\$ 0$ to $\$ 1000$ which they would be willing to pay or be paid annually on a per acre basis for eradication. Landowners who had wild hogs on their land but preferred fewer were grouped with those not wanting hogs because both associate negative values with wild hog presence. Other landowners, who desired to be supplemented for eradication because of the positive values they associated with wild hogs, were grouped together. This questionnaire assumes participants understood the hypothetical eradication would be permanent and that eradication costs would be shared regionally.

Alabama consists of physiographic regions with a variety of properties promoting or limiting the optimal growth of certain tree species. For this reason, the response data was organized by major physiographic regions of Alabama which include the Upper Coastal Plain (UCP), Black Belt Prairie (BBP), and Lower Coastal Plain (LCP). In most instances data were summarized by physiographic region in order to collect averages for questionnaire responses by region. Additionally, partial completion of surveys resulted in sample sizes for some questions to be quite small. Descriptive statistics were run on survey data using R Statistical Analysis Software (R Core Team 2013). 


\begin{tabular}{|c|c|c|c|c|c|c|}
\hline \multicolumn{7}{|c|}{ 1. In 2015, were any control methods used on your opera } \\
\hline \multicolumn{7}{|c|}{$\begin{array}{l}\text { 2. In } 2015 \text {, which of the following control methods were used on your operation in order to reduce or prevent damage } \\
\text { from wild pigs? If the method was used in } 2015 \text {, how much did that method cost (including labor) and how effective was } \\
\text { it? }\end{array}$} \\
\hline \multirow{2}{*}{ Control Method } & \multirow{2}{*}{$\begin{array}{l}\text { Used on } \\
\text { operation in } \\
\text { 2015? }\end{array}$} & \multirow{2}{*}{$\begin{array}{c}\text { Cost } \\
\text { (Include labor) } \\
\text { (Dollars) }\end{array}$} & \multicolumn{4}{|c|}{$\begin{array}{l}\text { How effective was the control method? } \\
\text { Check one per row }\end{array}$} \\
\hline & & & $\begin{array}{c}\text { Not } \\
\text { Effective }\end{array}$ & $\begin{array}{l}\text { Slightly } \\
\text { Effective }\end{array}$ & $\begin{array}{l}\text { Moderately } \\
\text { Effective }\end{array}$ & $\begin{array}{c}\text { Very } \\
\text { Effective }\end{array}$ \\
\hline a. Shooting wild pigs on sight & 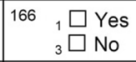 & $\begin{array}{l}167 \\
\$\end{array}$ & ${ }_{1} \square$ & ${ }_{2} \square$ & ${ }_{3} \square$ & ${ }_{4} \square$ \\
\hline b. Hunting wild pigs with dogs & $\begin{array}{cc}169 & 1 \\
& 1 \\
3 & \square \text { Yes } \\
\end{array}$ & $\begin{array}{l}170 \\
\$\end{array}$ & ${ }_{1} \square$ & ${ }_{2} \square$ & ${ }_{3} \square$ & ${ }_{4} \square$ \\
\hline $\begin{array}{l}\text { c. Hunting wild pigs without } \\
\text { dogs }\end{array}$ & $\begin{array}{cc}172 & 1 \\
& \square \text { Yes } \\
3 & \square \text { No }\end{array}$ & $\begin{array}{l}173 \\
\$\end{array}$ & ${ }_{1} \square$ & ${ }_{2} \square$ & ${ }_{3} \square$ & ${ }_{4} \square$ \\
\hline d. Aerial hunting (helicopter) & $\begin{array}{cc}175 & 1 \square \text { Yes } \\
& \\
3 & \square \text { No }\end{array}$ & $\begin{array}{l}176 \\
\$\end{array}$ & ${ }_{1} \square$ & ${ }_{2} \square$ & ${ }_{3} \square$ & ${ }_{4} \square$ \\
\hline $\begin{array}{l}\text { e. Trapping and removing wild } \\
\text { pigs }\end{array}$ & $\begin{array}{cc}178 & 1 \\
& 1 \\
& \square \text { Yes } \\
\end{array}$ & $\begin{array}{l}179 \\
\$\end{array}$ & ${ }_{1} \square$ & ${ }_{2} \square$ & ${ }_{3} \square$ & ${ }_{4} \square$ \\
\hline f. Repellents for wild pigs & $\begin{array}{rl}181 & 1 \\
& \square \text { Yes } \\
& \square \text { No }\end{array}$ & $\$$ & ${ }_{1} \square$ & ${ }_{2} \square$ & ${ }_{3} \square$ & ${ }_{4} \square$ \\
\hline $\begin{array}{l}\text { g. Other } \\
\text { (Specify: }\end{array}$ & $\begin{array}{rl}184 & 1 \\
& \square \text { Yes } \\
& \square \text { No }\end{array}$ & $\$$ & 186 & ${ }_{2} \square$ & ${ }_{3} \square$ & ${ }_{4} \square$ \\
\hline
\end{tabular}

3. In 2015 , did you use electric fencing on your operation specifically to reduce damage by wild pigs? 187

${ }_{1} \square$ Yes-Continue $\quad{ }_{3} \square$ No-Go to Item 4

a. How much did it cost to install this electric fencing?.

Dollars 188

b. At the time of installation, how many years was the expected useful life of this electric fencing?

\begin{tabular}{|c|}
\hline \multicolumn{1}{|c|}{ Years } \\
\hline 189 \\
\hline
\end{tabular}

4. In 2015 , did you use non-electric fencing on your operation specifically to reduce damage by wild pigs? 190

${ }_{1} \square$ Yes-Continue $\quad{ }_{3} \square$ No-Go to Item 5

a. How much did it cost to install this non-electric fencing?

19

b. At the time of installation, how many years was the expected useful life of this non-electric fencing?

5. In 2015 , how many wild pigs were killed on your land?

\begin{tabular}{|l|}
\hline \multicolumn{1}{|c|}{ Years } \\
\hline 192 \\
\hline
\end{tabular}

193

Fig. 2 Questions from the survey instrument concerning control methods employed on their land to manage wild hog populations in 2015

\section{Results}

Out of the 1160 surveys mailed to valid addresses, 406 landowners responded resulting in 352 usable surveys. A summary of responses by county based on physiographic region is illustrated in Fig. 4. The counties with the highest response rates $(\mathrm{n}=17)$ were Bullock, Coffee, Sumter, and Tallapoosa Counties. 


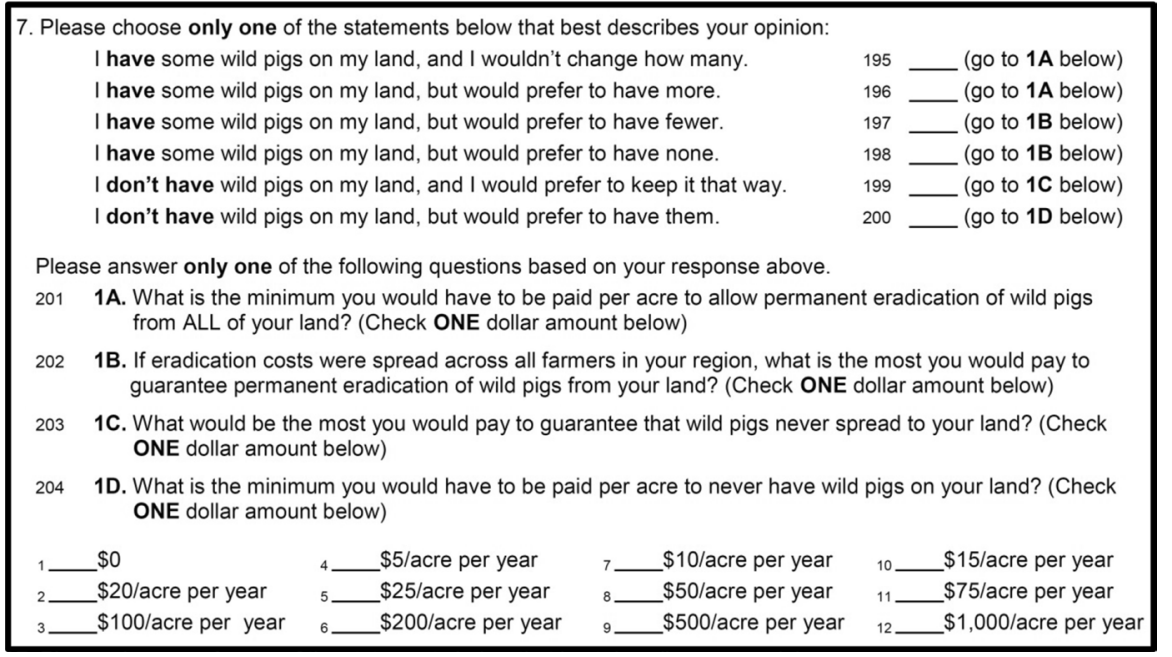

Fig. 3 Preference questionnaire for determining willingness to pay or to accept eradication of wild hogs from the 2016 survey of non-industrial private landowners in Alabama

Table 1 summarizes the number of responses by region and other relative information about forest plantations, damage, and control efforts. Responses were evenly distributed in proportion to how many counties constituted each region. Of the 352 survey respondents, almost $21 \%$ reported planting forest tree seedlings during 2013-2015 (Table 1). The number of respondents reporting some type of forest damage by wild hogs during this time varied by physiographic region with 9 landowners in the UCP, 21 in the BBP and 39 in the LCP reporting damage. Of the young forest plantations planted from 2013 to 2015, 19.6\% were reported to have sustained damage from wild hogs. Survey results indicate the BBP and the LCP had the largest sample of landowners reporting wild hogs on their land at approximately $70 \%$ and $54 \%$ respectively (Table 1 ). These two regions also reported a higher percentage of respondents used control methods at approximately $49 \%$ for the BBP, and $36 \%$ for the LCP. This is in contrast to only about $9 \%$ of respondents reporting attempting to control wild hogs in the UCP (Table 1). The highest numbers of hogs killed in 2015 were reported from the BBP (72 hogs) and LCP (23 hogs) (Table 1).

The results of seedling mortality due to wild hog activity and the associated costs with replanting are presented in Table 2. The top three tree species planted by landowners across the State from 2013 to 2015 were loblolly pine (Pinus taeda) $(n=41)$, longleaf pine $(n=32)$, and unspecified oak $(n=8)$. For pine stands planted in 2013-2015, the average number of acres planted was 130 and 47 for longleaf and loblolly, respectively. Of those areas planted it was reported that longleaf plantation had an average of 44 acres damaged by wild hogs (Table 2). Loblolly plantations had an average of 6 acres damaged. The percent of acres damaged was roughly the same however, with $23 \%$ for longleaf and $27 \%$ for loblolly. Assuming replanting occurred, we calculated the cost per acre to recover damaged portions at approximately $\$ 50$ and $\$ 25$ for longleaf and loblolly, respectively. These numbers are based 


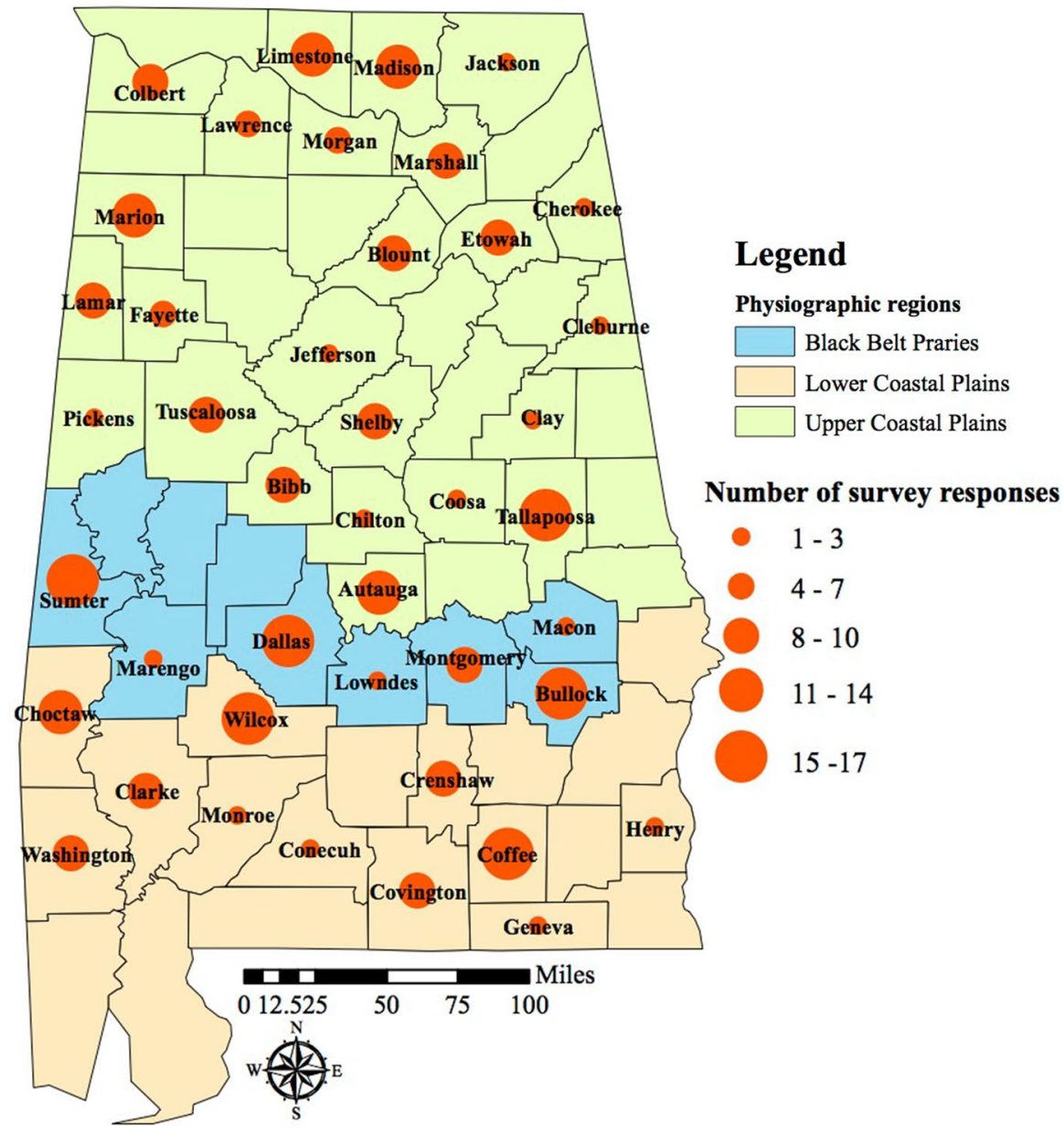

Fig. 4 Distribution and number of responses to the 2016 survey of wild hog damage to non-industrial private lands in Alabama. Counties are organized by major physiographic region

on 2016 seedling prices reported by Rayonier (Mark Davis, personal communication August 8, 2017) and planting costs from Maggard and Barlow (2017). No wild hog damage was reported in any of the hardwood plantations.

The average amount spent on control methods in each region is listed in Table 3. Landowners in the BBP reported spending, on average, \$258 when shooting on sight, \$398 when hunting without dogs, and \$891 when trapping (Table 3). The LCP had the greatest number of responses to this section and highest average expense paid by landowners to hunt with dogs at $\$ 212$. The percentage of landowners in each region who indicated using control methods, regardless of reported damage, is recounted in Table 4. The BBP was the only region that reported all control methods being utilized by landowners. For this region the most commonly implemented methods were shooting on sight (43.9\%) and trapping (40.4\%) (Table 4$)$. 


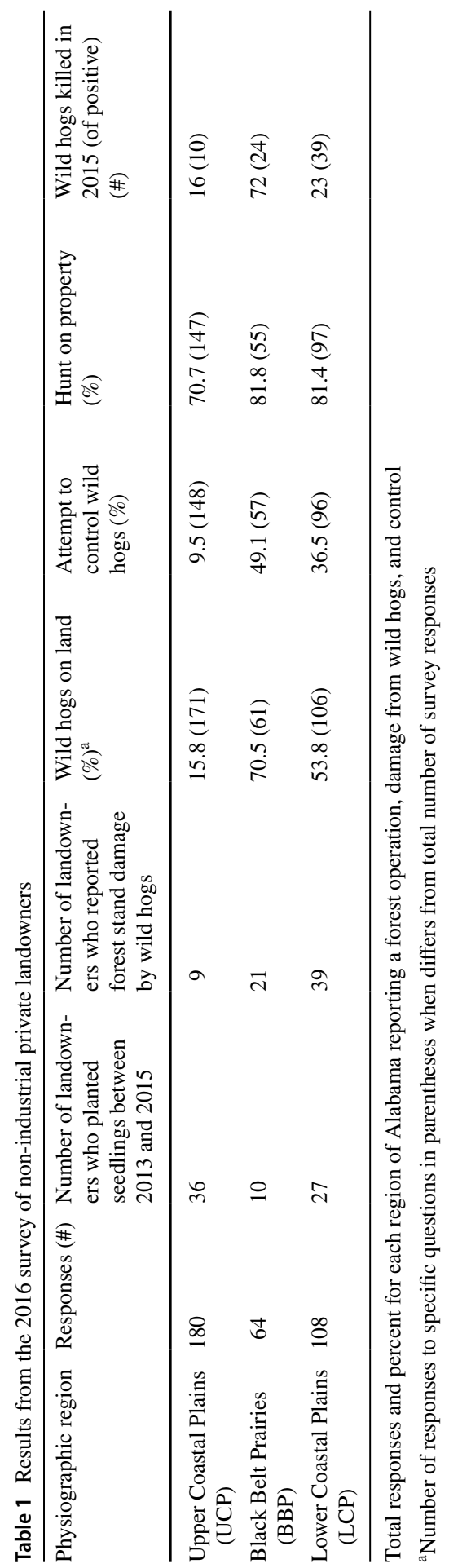


Table 2 Results from the timber stand section of the 2016 survey of non-industrial private landowners in Alabama

\begin{tabular}{lllllll}
\hline Species & $\begin{array}{l}\text { Number } \\
\text { reporting }\end{array}$ & $\begin{array}{l}\text { Size of } \\
\text { stand } \\
\text { (Acres) }\end{array}$ & $\begin{array}{l}\text { Trees per } \\
\text { acre planted }\end{array}$ & $\begin{array}{l}\text { Acres damage by } \\
\text { wild hogs (Acres) }\end{array}$ & $\begin{array}{l}\text { Percent of acre } \\
\text { damaged }(\%)\end{array}$ & $\begin{array}{l}\text { Replanting cost } \\
\text { due to }(\$ / \text { acre })^{\mathrm{a}}\end{array}$ \\
\hline Longleaf & 32 & 130 & 540 & 44 & 23 & 50.40 \\
Loblolly & 41 & 47 & 662 & 6 & 27 & 25.02 \\
Oak & 8 & 15 & 344 & 0 & - & - \\
\hline
\end{tabular}

Reported below are the averages for the forest stand information, wild hog damage, and calculated replanting cost per acre assuming respondents replanted after damage occurred

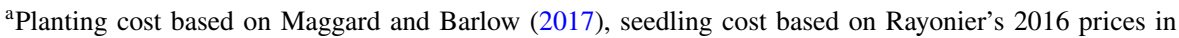
Alabama: \$0.40 and \$0.14 per seedling for longleaf and loblolly, respectively

Most respondents answering the willingness to pay/willingness to accept (WTP/ WTA) question indicated a preference for wild hog eradication (Table 5). From this sample, the number of landowners who wanted fewer/no wild hogs and were willing to pay for eradication was greater than the number of landowners who preferred having wild hogs on their property. Of those who had wild hogs on their property and preferred having them, only one respondent indicated they would want to be supplemented for accepting eradication (Table 5). Of the landowners who indicated a dollar amount they would be willing to pay for eradication, $43 \%$ said they would be willing to pay an average of $\$ 8.37 /$ acre/year (Table 5). The survey data suggests that landowners without wild hogs on their property currently were willing to pay more (\$22.40/acre/year) than those with wild hogs. In general, landowners in the BBP were willing to pay more per acre annually to eradicate wild hogs than landowners in the other two regions (Table 6).

\section{Discussion}

The primary goal of this project was to estimate the cost of wild hog damage to nonindustrial private landowner's young forest stands in Alabama. Our survey indicated that wild hog populations were distributed through all major physiographic regions in Alabama but appeared to have the greatest densities in the BBP and LCP. Interestingly, when timberland acres by forest type are considered for these two regions, they have higher percentages of softwood timberland acres than the UCP where $40 \%$ of timberland acres are classified as softwood forests (AFC 2020). Approximately $45 \%$ of timberland acres in the BBP are softwood forests while the LCP has the greatest percentage of softwood timberland acres at 54\% (AFC 2020).

For landowners in these regions who planted trees during this time, $19.6 \%$ had wild hog damage to their young forest stands. Survey results indicated that wild hogs damaged approximately the same percentage of acres in longleaf plantations (23\%) as in loblolly plantations (27\%). Wild hog damage to longleaf pine seedlings has long been a topic of concern (Wahlenberg 1946; Wakeley 1954). While this study shows that hog damage impacted both longleaf and loblolly seedlings, 


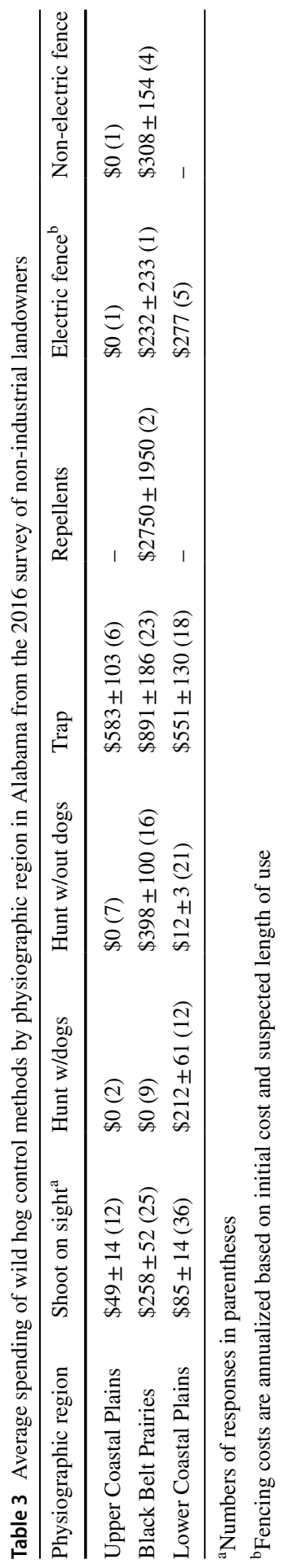


Table 4 Percentage of responses reporting use of control methods by physiographic region in Alabama from the 2016 survey of non-industrial landowners

\begin{tabular}{llllllll}
\hline $\begin{array}{l}\text { Physiographic } \\
\text { region }\end{array}$ & $\begin{array}{l}\text { Shoot } \\
\text { on sight } \\
(\%)\end{array}$ & $\begin{array}{l}\text { Hunt w/dogs } \\
(\%)\end{array}$ & $\begin{array}{l}\text { Hunt w/ } \\
\text { out dogs } \\
(\%)\end{array}$ & Trap (\%) & $\begin{array}{l}\text { Repellents } \\
(\%)\end{array}$ & $\begin{array}{l}\text { Electric } \\
\text { fence } \\
(\%)\end{array}$ & $\begin{array}{l}\text { Non-elec- } \\
\text { tric fence } \\
(\%)\end{array}$ \\
\hline $\begin{array}{c}\text { Upper Coastal } \\
\text { Plains }\end{array}$ & 5.9 & 1.0 & 3.4 & 2.9 & 0.0 & 0.5 & 0.5 \\
$\begin{array}{c}\text { Black Belt } \\
\text { Prairies }\end{array}$ & 43.9 & 15.8 & 28.1 & 40.4 & 3.5 & 1.8 & 7.0 \\
$\begin{array}{c}\text { Lower Coastal } \\
\text { Plains }\end{array}$ & 37.5 & 12.5 & 21.9 & 18.8 & 0.0 & 5.2 & 0.0 \\
\hline
\end{tabular}

Table 5 Alabama landowners' average reported willingness to pay (WTP) for or willingness to accept (WTA) wild hog eradication (\$ per acre/year) from the 2016 survey of non-industrial private landowners

\begin{tabular}{llrll}
\hline & Pigs on land & $\mathrm{n}$ & Average (\$) & $\begin{array}{l}\text { Standard } \\
\text { error of the } \\
\text { mean }\end{array}$ \\
\hline WTP for eradication & $\mathrm{N}$ & 151 & $\$ 22.40$ & \pm 1.82 \\
(prefer fewer/none) & $\mathrm{Y}$ & 114 & $\$ 8.37$ & \pm 0.96 \\
WTA eradication & $\mathrm{N}$ & 5 & - & - \\
(prefer them) & $\mathrm{Y}$ & 9 & $\$ 71.43$ & \pm 23.81 \\
\hline
\end{tabular}

Table 6 Average reported willingness to pay (WTP) for wild hog eradication (\$ per acre/year) by physiographic region in Alabama from the 2016 survey of non-industrial private landowners

\begin{tabular}{lllcc}
\hline Physiographic region & Pigs on land & $\mathrm{n}$ & Average (\$) & $\begin{array}{c}\text { Standard error } \\
\text { of the mean }\end{array}$ \\
\hline Upper Coastal Plains & $\mathrm{N}$ & 63 & $\$ 7.65$ & \pm 0.96 \\
& $\mathrm{Y}$ & 43 & $\$ 6.63$ & \pm 1.01 \\
Black Belt Prairies & $\mathrm{N}$ & 10 & $\$ 206.00$ & \pm 65.19 \\
& $\mathrm{Y}$ & 29 & $\$ 11.03$ & \pm 2.05 \\
Lower Coastal Plains & $\mathrm{N}$ & 26 & $\$ 5.58$ & \pm 1.09 \\
& $\mathrm{Y}$ & 47 & $\$ 6.81$ & \pm 0.99 \\
\hline
\end{tabular}

the economic impact to a landowner is not necessarily equal. Containerized longleaf seedlings cost $65 \%$ more than bareroot loblolly seedlings. Due to the higher seedling cost and wild hog damage associated with longleaf, we recommend landowners in the longleaf pine range invest in wild hog control to protect their plantation during the first three growing seasons. However, early rotation forest stand protection is important regardless of species. Timber has a typical rotation age of 25 years or more, making it a long-term investment and not an annual crop; therefore, financial losses due to lost growth in the first few years of a forest stand are compounded over many years. 
The results from the willingness to pay question suggest Alabama landowners are primarily in favor of wild hog eradication. The results were heavily weighted towards those who preferred fewer/no wild hogs if present on their property, or if not present, preferred to keep it that way. Of those who were willing to pay for wild hog eradication, a few landowners without wild hogs on their property were willing to pay a premium on prevention. Out of the nine respondents who felt they benefitted from wild hogs on their property, only one individual felt they needed to be compensated to allow wild hog eradication. This individual did not report making any income from wild hog hunting. These findings suggest the positive values respondents associate with wild hogs on their property cannot be explained by the financial benefits alone. Around 56 percent of landowners who preferred the presence of wild hogs on their property indicated they hunted the animals; therefore, these landowners likely place a high value on having wild hogs available to hunt.

A few limitations should be acknowledged concerning the survey and its analysis. First, it is possible that landowners did not have an accurate perception of damage done to their forest stand, and their costs spent on control methods could have been biased. The survey required respondents to recall a number of different figures and expenditures so these biases could have been intentional or unintentional. Secondly, a non-response bias may exist despite efforts taken to reduce such a bias. A $35 \%$ response rate is acceptable but a bias could still be possible because landowners with wild hogs on their property or in the area are more likely to respond than those without.

In this study we sought to fill in the information gap concerning wild hog impacts on young forest plantations. Considerable effort is expended to manage wild hog populations by individuals, state, and government agencies, and results from this study could help these entities allocate resources to regions where wild hog problems are most severe. It also illuminates what lengths landowners were willing to go to eradicate wild hogs from, or prevent them from residing on, timberland in Alabama.

Funding This work was supported by the United States Department of Agriculture's National Wildlife Research Center, Fort Collings, CO [grant number 15-7483-1217-CA].

\section{References}

Alabama Forestry Commission (AFC) (2020) Forest resource report 2019. https://forestry.alabama.gov/ Pages/Management/Forms/Forest_Resource_Report_2019.pdf. Accessed 24 Sept 2020

Anderson A, Slootmaker C, Harper E, Holderieath J, Shwiff SA (2016) Economic estimates of feral swine damage and control in 11 US states. Crop Prot 89:89-94

Conley RE, Smith MD, Armstrong JB (2014) Mapping the distribution of wild pigs in Alabama. In: 2014 international wild pig conference, Montgomery, Alabama. Abstract, Auburn University

Davis M (2017) Elberta Nursery Director, Rayonier, personal communication, August 8, 2017

Dillman DA, Smyth JD, Christian LM (2014) Internet, phone, mail, and mixed-mode surveys: the tailored design method, 4th edn. Wiley, pp 351-396 
Engeman RM, Smith HT, Shwiff SA, Constantin B, Woolard J, Nelson M, Griffin D (2003) Prevalence and economic value of feral swine damage to native habitat in three Florida state parks. Environ Conserv 30(4):319-324

Fern MP, Armstrong JB, Barlow RJ, Kush JS (2020) Ecological factors influencing wild pig damage to planted pine and hardwood seedlings. Hum-Wildl Interact 14(2):12

Herrero J, García-Serrano A, Couto S, Ortuño VM, García-González R (2006) Diet of wild boar (Sus scrofa L.) and crop damage in an intensive agroecosystem. Eur J Wildlife Res 52(4):245-250

Jaworowski C (2011) Hogs gone wild: controlling feral hogs. Alabama's TREASURED Forests. Alabama Forestry Commission, fall/winter edition, 13-15

Maggard A, Barlow R (2017) Costs and trends of southern forestry practices, 2016. Alabama Cooperative Extension System. http://www.aces.edu/pubs/docs/F/FOR-2051/FOR-2051.pdf. Accessed 1 Sept 2017

Mayer J (2009) Wild pig damage: overview of wild pig damage. In: Mayer JJ, Brisbin IL Jr (eds) Wild pigs: biology, damage, control techniques and management. Savannah River National Laboratory, Aiken, South Carolina, USA. SRNL-RP-2009-00869, pp 221-246

R Core Team (2013) R: a language and environment for statistical computing. R Foundation for Statistical Computing, Vienna, Austria. http://www.R-project.org/

Schley L, Dufrêne M, Krier A, Frantz AC (2008) Patterns of crop damage by wild boar (Sus scrofa) in Luxembourg over a 10-year period. Eur J Wildlife Res 54(4):589-599

Schley L, Roper TJ (2003) Diet of wild boar Sus scrofa in western Europe, with particular reference to consumption of agricultural crops. Mammal Rev 33(1):43-56

Seward NW, VerCauteren KC, Witmer GW, Engeman RM (2004) Feral swine impacts on agriculture and the environment. Sheep Goat Res J 19:34-40

United States Department of Agriculture (USDA) (2016) 2016 State agriculture overview: Alabama. United Sates Department of Agriculture, National Agricultural Statistics Service. http://www.nass. usda.gov/Quick_Stats/Ag_Overview/stateOverview.php?state=ALABAMA. Accessed 5 Sept 2017

Wahlenberg WG (1946) Longleaf pine: its use, ecology, regeneration, protection, growth, and management. Washington, D.C. Charles Lathrop Pack Forestry Foundation, in cooperation with the U.S. Department of Agriculture, Forest Service. 429

Wakeley PC (1954) Planting the southern pines. Forest Service, U.S. Department of Agriculture, Agriculture Monograph No. 18. Washington, D.C.

Publisher's Note Springer Nature remains neutral with regard to jurisdictional claims in published maps and institutional affiliations.

\title{
Authors and Affiliations
}

\section{Micah Fern ${ }^{1}$ (D) Rebecca Barlow ${ }^{2}$. Chris Slootmaker ${ }^{3}$. John Kush ${ }^{2}$. Stephanie Shwiff ${ }^{4}$. Larry Teeter ${ }^{2}$. Jim Armstrong ${ }^{2}$}

\author{
Rebecca Barlow \\ rbj0003@auburn.edu \\ Chris Slootmaker \\ Chris.slootmaker@gmail.com \\ John Kush \\ kushjoh@auburn.edu \\ Stephanie Shwiff \\ Stephanie.A.Shwiff@aphis.usda.gov \\ Larry Teeter \\ teeteld@auburn.edu \\ Jim Armstrong \\ armstjb@auburn.edu
}


1 Union University, 1050 Union University Drive, UU Box 3128, Jackson, TN 38305, USA

2 Auburn University, 602 Duncan Drive, Auburn, AL 36849, USA

3 Mountain Data Group, 115 North College Avenue, Fort Collins, CO 80524, USA

4 National Wildlife Research Center, 4101 LaPorte Avenue, Fort Collins, CO 80521, USA 